\title{
Insuring Large-Scale Floods in the Netherlands
}

\author{
Ruben Jongejan $^{\mathrm{a}}$ and Pauline Barrieu ${ }^{\mathrm{b}}$ \\ ${ }^{a}$ Hydraulic Engineering, Delft University of Technology, Stevinweg 1, 2628CN Delft, \\ P.O.Box 5048, 2600GA The Netherlands. \\ E-mail: R.B.Jongejan@tudelft.nl \\ ${ }^{\mathrm{b}}$ Department of Statistics, London School of Economics, Houghton Street, London, WC2A 2AE United \\ Kingdom. \\ E-mail: p.m.barrieu@1se.ac.uk
}

Without its primary flood defenses, a large part of the Netherlands would be swallowed by rivers and the sea. Floods caused by the failure of primary flood defenses are high-impact, low-probability events that are notoriously difficult to insure. Private insurance was long considered unfeasible but the Dutch government is currently studying ways to introduce a public-private insurance program. This paper offers a discussion of variables that should be taken into account in the choice for an arrangement for the financing of large-scale floods in the Netherlands. Because flood risk is highly concentrated and potential losses could be severe, a strong government role seems inevitable. But this would not necessarily be inappropriate as this could reduce the risk of underinvestment in flood protection.

The Geneva Papers (2008) 33, 250-268. doi:10.1057/gpp.2008.10

Keywords: flood insurance; flood protection; large-scale risk

\section{Introduction: the insurability of floods}

Recent floods in New Orleans and the United Kingdom have demonstrated the devastating impact of large-scale floods in densely populated regions. Such tragic events can never be completely prevented and are notoriously difficult to insure. Governments have responded in a wide variety of ways to the challenges posed by the uninsurability of low-probability, large-scale natural disasters. Such differences can be traced back to institutional variables, characteristics of national insurance markets, and differences between flood risks. These differences make it impossible to define a universal panacea: an insurance arrangement that works in one country need not work in another. ${ }^{1}$

Current schemes for providing financial compensation for large-scale disasters can be grouped into four broad categories. ${ }^{2}$ First, governments could rely on liability and social security. Additional support could be offered on a discretionary, ad hoc basis. This approach has been followed in, for instance, Germany. After the 2002 floods, the German government and the public offered strong financial support to flood victims, even though private insurance coverage had been available. ${ }^{3}$

\footnotetext{
${ }^{1}$ Swiss Re (1998a).

${ }^{2}$ Faure (2006); Faure and Hartlief (2006).

${ }^{3}$ Thieken et al. (2006).
} 
Second, governments could mandate that coverage for natural disasters be tied to first-party insurances, such as fire insurance. In France, a state-run reinsurance company offers coverage against natural disasters. Premiums are statutorily included in first-party property insurances. Whether victims are compensated under this mandatory program is up to the government to decide. The system is based on solidarity but because the different parts of the country are exposed to different natural perils (hail, windstorm, flood, earthquake), it seems unlikely that policyholders would only subsidize others. ${ }^{4}$ A broadly similar approach has recently been adopted in Belgium. Insurers in Belgium have to add a premium to fire insurances. These premiums are used to establish a fund for natural disasters such as floods and earthquakes.

Third, governments could establish compensation funds to (partially) indemnify victims of natural disasters. Fund build-up is a feature of several government natural disaster programs, such as the California Earthquake Authority (CEA), the Florida Hurricane Catastrophe Fund, the Icelandic Catastrophe Fund, and the New Zealand Earthquake Commission. ${ }^{5}$ The CEA was established by the state of California to insure its residents against earthquakes. The CEA obtains its funds through premiums, contributions from member insurance companies, debt issuance, reinsurance, and investment. ${ }^{6}$ The CEA demonstrates that a calamities fund does not need to be funded by a government.

Fourth, governments could establish public-private partnerships to stimulate the availability of insurance coverage. The government-run National Flood Insurance Program (NFIP) offers flood insurance in the United States. The federal government provides underwriting capacity, and policies are written and claims handled by insurance companies. The NFIP has made flood insurance available for the majority of properties and contents in regions where flood risks have been assessed and flood risk mitigation programs are in place. ${ }^{7}$ In the United Kingdom, a "Gentlemen's Agreement" between the government and the insurance industry ensures the provision of flood insurance by private enterprise. Underinvestment in flood protection has however put the agreement under strain and has led insurance companies to differentiate premiums and reconsider the unconditional nature of insurance coverage. ${ }^{8}$

As the latter example illustrates, present-day insurance arrangements are by no means perfect or static. Frequencies and impacts of natural disasters have changed, ${ }^{9}$ and advances in risk modeling and financial innovations in insurance markets have extended the limits of insurability. ${ }^{10}$ Insurance arrangements should ideally serve as efficient mechanisms for risk transfer and provide adequate incentives for loss prevention. But deciding on appropriate changes to current schemes is by no means straightforward. While some stress the need for deregulation and restraints on government relief to allow insurance markets to function, ${ }^{11}$ others stress the need for

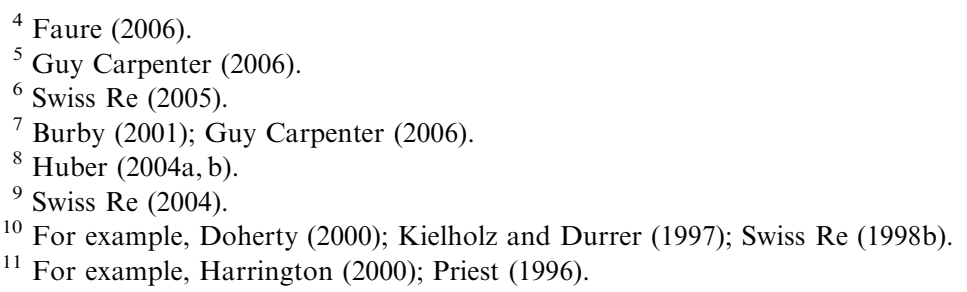


government support to stimulate or supplement private sector initiatives. ${ }^{12}$ A study about ways to increase the supply of property and casualty insurance by the U.S. Congressional Budget Office clearly reflects the discrepancy in suggested solutions. ${ }^{13}$

This paper focuses on the introduction of a flood insurance program in the Netherlands, a topic that has gained a prominent position on the Dutch political agenda in recent years. It should be noted that the issue of flood insurance stands largely on its own (or at least it is treated that way) and that it is not (treated as) an integral part of the Dutch flood safety policy. Floods that are currently uninsurable range from high ground water levels caused by heavy rainfall to large-scale floods caused by the failure of coastal barriers and river dikes. ${ }^{14}$ This paper is concerned exclusively with the high-consequence, low-probability floods that could result from failures of primary flood defenses such as river dikes and coastal defenses.

Insurance against large-scale floods is currently unavailable in the Netherlands and the country lacks a flood insurance program. The government has long relied on discretionary, ad hoc support to victims of disasters but the attitude towards flood insurance in the Netherlands has changed markedly over the past few years. ${ }^{15}$ Following a number of instances in which the government decided to offer compensation, a committee was installed to evaluate the government's framework for dealing with uninsured losses. ${ }^{16}$ One of the committee's recommendations was to consider private sector solutions for supposedly uninsurable events, a recommendation that was then turned into a cabinet decision. ${ }^{17}$ In 2006, the Water Advisory Council then proposed the introduction of a private flood insurance program. ${ }^{18}$ That same year, a government taskforce took on the challenge to turn this vision into a reality.

But how to devise a flood insurance program for the Netherlands? While psychological and multi-actor studies could elicit interests and opinions ${ }^{19}$ and thereby point to politically feasible solutions or necessary institutional changes to turn visions into realities, a different approach is taken here. Our main objective is to underline the key variables that should be taken into consideration in the choice for an arrangement for the financing of large-scale floods in the somewhat exceptional Dutch case, as well as to sketch the outline of a possible insurance solution.

The paper is organized as follows. In the following section, several important characteristics of large-scale floods in the Netherlands are discussed and the formal outline of the Dutch flood safety policy is briefly introduced. The next section then

\footnotetext{
${ }^{12}$ For example, Cummins et al. (1999); Kunreuther and Pauly (2006).

${ }^{13}$ Congressional Budget Office (2002).

${ }^{14}$ Kok (2005).

15 For example, Hartlief (2006).

${ }^{16}$ Disasters and Calamities Compensation Committee (2004).

${ }^{17}$ Cabinet opinion in consideration of the final report of the Calamities and Disasters Committee "Solidarity and Policy" (2005) (in Dutch: "Kabinetsstandpunt naar Aanleiding van het Eindrapport van de Commissie Tegemoetkomingen bij Rampen en Calamiteiten 'Solidariteit met Beleid"').

${ }^{18}$ Water Advisory Council (2006, p. 17).

${ }^{19}$ See e.g. Vari et al. (2003) for a study about stakeholder views on flood risk mitigation and flood insurance.
} 
studies the reasons behind the uninsurability of large-scale floods in the Netherlands. The penultimate section then discusses a possible outline of a possible public-private partnership in a step-by-step manner. The last section summarizes the main results and offers suggestions for further research.

\section{Important characteristics of large-scale floods in the Netherlands}

Numerous comparative studies have been published on flood insurance programs in different countries. ${ }^{20}$ Even if they provide a highly useful stepping stone, one has to consider some characteristics that make the Dutch case stand out when evaluating the applicability of these studies to the Dutch context.

First, flood risk in the low-lying Netherlands is highly concentrated. A significant portion (over 60 per cent) of the Dutch population lives in flood-prone areas and a significant percentage of national income is earned below sea level. The densely populated Zuidplaspolder (1840) near Rotterdam lies $6 \mathrm{~m}$ below mean sea level and Schiphol airport, the Dutch national airport, lies about $4.5 \mathrm{~m}$ below mean sea level. This is due to the history of the Dutch territory, which is marked by dike construction, polders, and land reclamation (Figure 1). Although the simultaneous flooding of all low-lying areas in the Netherlands would be extremely unlikely, floods could cause losses in the tens of billions of euros. ${ }^{21}$

To ensure a high standard of protection against large-scale floods, primary flood defenses have to meet stringent probabilistic design standards that have been laid down in the Flood Defense Act. ${ }^{22}$ As shown by Figure 2, the statutory design standards for primary flood defenses vary throughout the country. This is a consequence of the use of cost-benefit analysis to derive/rationalize these standards (or more precisely: design loads). In these studies, discounted investments in flood defenses are balanced against the reduction in the discounted expected value of future losses. ${ }^{23}$ The economically most important regions are thus best protected.

It should be noted that the safety standards shown in Figure 2 correspond to the excess frequencies of design water levels. These should not be confused with flood probabilities. While the design standard for the primary flood defenses of Central Holland is a water level with an excess frequency of $1 / 10,000$ per year, the probability of flood has recently been estimated at 1/2,500 per year. ${ }^{24}$ First, the Flood Defense Act is concerned with only one failure mode (overtopping), whereas there are various other modes that determine the probability of failure of a flood defense. Second, the standards are imposed on individual dike sections, whereas the probability of flood depends on the strength of the entire dike ring. Third, the design standards lay down minimum requirements. Constructing a higher levee than strictly required allows the Dutch to economize on the fixed costs of future dike heightening. The level of flood

\footnotetext{
${ }^{20}$ See e.g. Swiss Re (1998b) for an extensive overview.

${ }^{21}$ Ministry of Transport, Public Works and Water Management (2005).

${ }^{22}$ Flood Defence Act (1995).

${ }^{23}$ Van Dantzig (1956).

${ }^{24}$ Ministry of Transport, Public Works and Water Management (2005).
} 

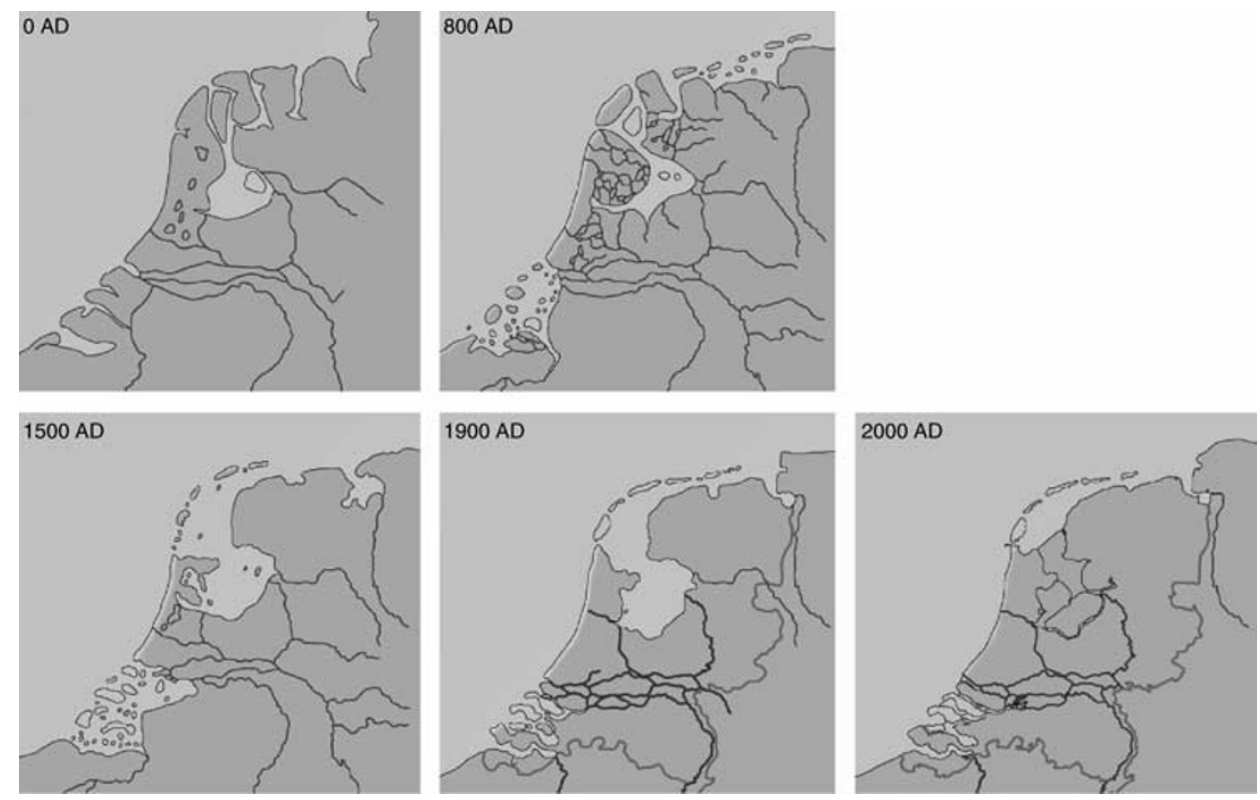

Figure 1. The face of the Netherlands at approximately 0, 800, 1500, 1900, and 2000 AD. Source: Huisman (2004, p. 34).

safety may thus well be higher than what would follow from the minimal requirements. But as shown by a recent review of the primary flood defenses, ${ }^{25}$ their condition could also be poorer than what one would expect on the basis of the Flood Defense Act. Still, large-scale floods in the Netherlands are extremely unlikely.

As the above already indicates, flood protection in the Netherlands is publicly provided. The Dutch initially constructed artificial hills to retreat on during periods of high water. People then decided to act collectively and protect low-lying, arable land by dikes. Water boards were established from the 13th century onwards to raise funds for dike construction (prevent free-riding) and coordinate individual efforts. Nowadays, responsibilities for water management are divided between the national government, provinces, and the water boards. When densely populated regions have to be protected from floods, dikes become very cost-effective compared to individual efforts such as flood proofing infrastructures and houses. Despite the Dutch topography, only 0.15 per cent of NNP is spent annually on flood protection. ${ }^{26}$ The fact that flood protection is provided by government organizations that act on behalf of exposed populations has important implications for the issue of moral hazard (as we will discuss in the next section).

\footnotetext{
${ }^{25}$ Ministry of Transport, Public Works and Water Management (2006).

${ }^{26}$ RIVM-MNP (2004).
} 


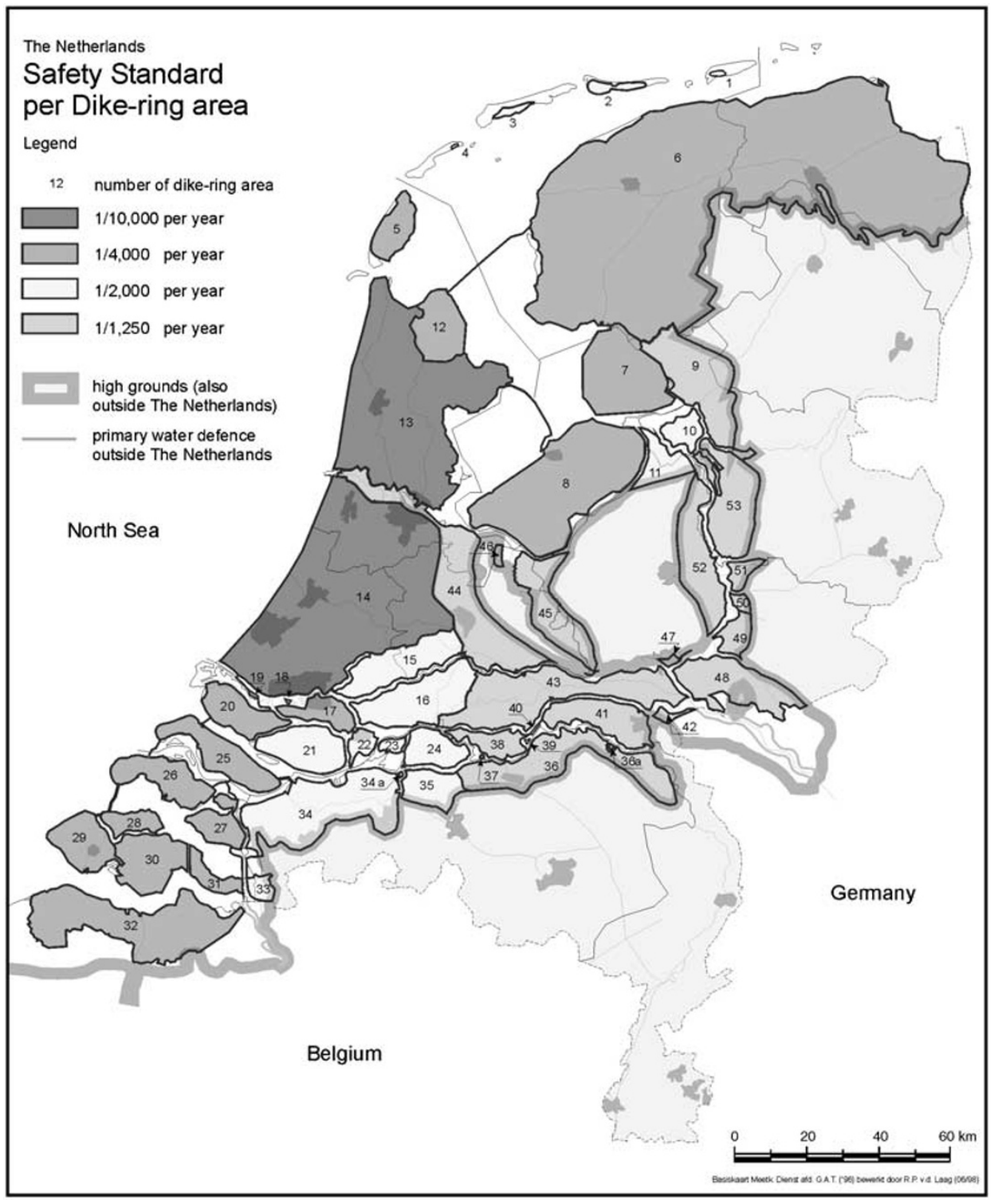

Figure 2. Statutory design standards for the Dutch primary flood defenses.

\section{About the uninsurability of flood risks in the Netherlands}

\section{Historical background}

Because of the scale of potential damages, private insurance against large-scale floods in the Netherlands has long been considered unfeasible. In 1955, after a major flood in 1953 in the south-western part of the Netherlands, the organization of Dutch insurers 
issued a binding agreement forbidding its members to insure flood damages caused by the failure of flood defenses out of concerns over business continuity. ${ }^{27}$ After a period of relative calm, disaster insurance was brought back on the political agenda by a relatively minor earthquake near Roermond in 1992 and the near-floods of 1993 and 1995. The Dutch government entered into a covenant in 1995 with the Dutch Association of Insurers. The purpose of the covenant was to establish a calamities fund that was to be filled with contributions levied on property and household insurance purchases.

But the Council of State (in Dutch: "Raad van State"), the Dutch supreme administrative court and an independent advisory body, advised against the covenant. ${ }^{28}$ The Council stated that lack of solidarity had never been in the way of government compensation before and referred to Article 21 of the Dutch constitution that stipulates that the government is responsible for the "habitability of the land." Furthermore, it emphasized that lack of a sizeable contribution by the government would deny its responsibility for events that could threaten national interests. The Council also raised awareness for the seemingly generous remuneration of insurers and saw no principal reason why fire insurers would have to finance flood risks (flood insurance would be tied to fire insurance, similar to the recent Belgian insurance program for natural perils ${ }^{29}$ ). Finally, the Council posed that the proposed covenant would probably make itself obsolete after the execution of the Delta Plan for the Rivers. This optimism proved to be in vain however: currently, there is no insurer offering coverage against losses from large-scale floods in the Netherlands. Because of the Council's negative advice, the government decided not to send its proposal to parliament and the covenant was dismissed.

The agreement between Dutch insurers to not underwrite large-scale floods was withdrawn in 1998 because of pressures from the European Union. ${ }^{30}$ In that same year, the Calamities Compensation Act (WTS) was enacted. The WTS was intended to bring an end to the ad hoc responses of the government to large-scale accidents. ${ }^{31}$ But although the WTS does not cover damages for which private insurance is available, the government has often compensated damages that could have been insured. ${ }^{32}$ This, then, led to a cabinet decision to extend the limits of insurability. But how to insure flood damages that could exceed tens of billions of euros?

If capital markets were to operate perfectly, large-scale floods would be perfectly insurable. After all, capital markets allow insurers to pool flood risks in the Netherlands with numerous other risks around the globe (daily fluctuations on global

${ }^{27}$ Kok (2005).

${ }^{28}$ Raad van State (1996).

${ }^{29}$ Law to change, concerning the insurance against natural disasters, the law of 25 June 1992 on the country insurance agreement, and the law of 12 July 1976 concerning the reparation of damages to private goods caused by natural disasters, 2005 (in Dutch: "Wet tot wijziging wat de verzekering tegen natuurrampen betreft, van de wet van 25 juni 1992 op de landverzekeringsovereenkomst en de wet van 12 juli 1976 betreffende het herstel van zekere schade veroorzaakt aan private goederen door natuurrampen").

${ }^{30}$ Kok (2005); Faure (2006).

${ }^{31}$ De Vries (1998).

${ }^{32}$ Disasters and Calamities Compensation Committee (2004). 
capital markets are in the order of 100 billion euros). Problems concern both the supply and demand sides of insurance. But before considering these issues, let us first consider three issues that are often believed to be causes of the uninsurability of largescale natural disasters: adverse selection, moral hazard, and the uncertainty surrounding risk estimates.

\section{Adverse selection, moral hazard, and uncertainty}

When insurers cannot price coverage on the basis of individual exposures, insurers have to charge low risk individuals relatively high premiums. And this in turn reduces the attractiveness of insurance to low risk individuals. This problem, called adverse selection, is the result of information asymmetries between the insured and the insurer. ${ }^{33}$ Information on the probability and severity of large-scale natural events is however public rather than private. ${ }^{34}$ Moreover, the insured have no control over the probability of high river discharges or storm surges. The problem of adverse selection could be overcome by allowing insurers to set premiums in accordance with individual exposures or by making insurance compulsory.

Moral hazard also results from information asymmetries. People might lose an incentive to be careful and avoid damages when they are insured and the insurer is unable to monitor their behavior. The problem of moral hazard can be reduced by means of, for example, coinsurance, deductibles or caps. ${ }^{35}$ It is important to realize that the provision of flood safety in the Netherlands concerns the provision of a public good, as discussed in the previous section. The national government, provinces and water boards are responsible for looking after the primary flood defense system. If flood damages were financed by (re)insurers, the government would lose an important incentive to properly look after the flood defenses. That said, a considerable portion of the damages caused by floods concern public sector damages. In the 2002 floods in Germany, only 45 per cent of the losses were suffered in the private sector. ${ }^{36}$ Damages to private properties have been estimated to constitute about 60 per cent of total damage in the Netherlands. ${ }^{37}$ The remaining 40 per cent could perhaps be interpreted as the government's deductible. But the issue of under-deterrence remains. This is not just a purely hypothetical risk. Moral hazard on the part of the British government seems to have led to considerable underinvestment in flood protection in the United Kingdom. ${ }^{38}$ And as shown by the most recent review of the Dutch primary flood defenses, it is by no means obvious that the Dutch government lives up to its Flood Defense Act.

But what about measures that individuals could take themselves? Or, put differently, what about moral hazard on the part of individuals? While there are numerous measures that would be effective to reduce flood risks (e.g. flood proofing

\footnotetext{
${ }^{33}$ See also Rees (1985a, b).

34 Jaffee and Russell (1997).

35 Arrow (1971).

${ }^{36}$ Thieken et al. (2006).

${ }^{37}$ Kok et al. (2002).

${ }^{38}$ Huber (2004a, b).
} 
houses), the key question is which ones would be most cost-effective, for a dollar can be spent only once. The most cost-effective measure, that is, constructing and maintaining flood defenses, requires a collective effort. Money spent by millions of households on measures that mitigate the consequences of large-scale floods would certainly be better spent on flood defenses that benefit them all. Dutch citizens pay taxes to a government that looks after flood defenses on their behalf. And because taxation is compulsory, individuals cannot escape their responsibility to contribute.

Finally, let us consider the uncertainty surrounding risk estimates. It is obviously troublesome to make actuarially sound loss estimates for low-probability events on the basis of observed frequencies. But advanced flood risk models have been and are being developed in the Netherlands for estimating flood risks. ${ }^{39}$ Moreover, the absence of reliable probability estimates has not hampered the operation of marine insurance markets in the distant past. ${ }^{40}$ But when neither adverse selection, moral hazard nor the uncertainty surrounding risk estimates are a real issue, why would coverage against major floods in the Netherlands currently be unavailable? It seems that problems with supply and demand are to blame.

\section{Supply-side restrictions: cat-insurance might be relatively costly}

Insurers could pay for annual losses out of annual premiums with relatively little capital in reserve by pooling a large number of uncorrelated risks in a single portfolio. But low-probability large-scale events are difficult to diversify cross-sectionally and could give rise to a highly variable loss pattern. And because a large-scale event with a probability of $10^{-4}$ per year might just as well occur tomorrow, a large reserve would be needed to be sure that claims can be settled. Other than retaining risks and keeping sufficient capital in reserve, primary insurers could purchase insurance themselves (reinsurance). But although reinsurers are at a comparative advantage over regionally operating primary insurers when it comes to geographical risk spreading, they would still face a relatively variable annual loss pattern if they were to take on low probability events that could give rise to losses in the billions of euros.

An insurer that pools an infinite number of uncorrelated risks would be able to sell insurance against expected loss, the "actuarially fair premium." But how does reality compare to this ideal world? Froot has demonstrated that the premiums for reinsurance contracts for low-probability, large-scale losses are typically a multiple of expected loss. ${ }^{41}$ It is illustrative that British Petroleum decided to self-insure against losses exceeding $\$ 500$ million, primarily because of the costs of coverage for losses in that range. ${ }^{42}$

Various explanations have been put forward in literature for the high costs of insurance against low-probability catastrophes, including market power, agency cost, transaction cost, moral hazard, adverse selection, disaster relief, tax provisions, and

\footnotetext{
${ }^{39}$ For example, Ministry of Transport, Public Works and Water Management (2005).

${ }^{40}$ Jaffee and Russell (1997).

${ }^{41}$ Froot (2001).

${ }^{42}$ Doherty and Smith Jr. (1993).
} 
regulation. ${ }^{43}$ Compelling evidence has been found for the presence of capital market imperfections that make it costly to raise external capital. It is well documented that the price of reinsurance rises and the quantity of reinsurance purchases drops in the wake of large-scale losses. This could perhaps be explained by probability updating, that is, catastrophes change probability and loss estimates. But the occurrence of a hurricane provides little information about earthquake risks, while major disasters raise prices throughout the reinsurance industry. This lends support to the hypothesis that it is costly for the reinsurance industry to attract the external capital needed to supplement a depleted capital stock after a major disaster. ${ }^{44}$

New capital market instruments have been developed for the insurance of largescale risks, such as cat-bonds. ${ }^{45}$ But so far, these securities have by no means driven the costs of coverage for low probability, multi-billion euro losses down to expected loss. ${ }^{46}$ Despite recent capital market innovations, the costs of private (re)insurance for large-scale floods in the Netherlands, without considerable government support, should be expected to be well above expected loss. Flood insurance might even be so costly that few would be willing to purchase it.

The Dutch Association of Insurers has repeatedly stressed the impossibility of a purely private insurance program. ${ }^{47}$ To put the capacity of the Dutch insurance industry into perspective, consider the following figures: the Dutch Terrorism Risk Reinsurance Company (NHT) provides a capacity of up to 1 billion euros for annual industry-wide terrorism-related losses in the Netherlands, the total premium volume for fire insurance in the Netherlands is about 3.2 billion euros, and the surplus on all non-life and non-health policies was just over 1 billion euros (before taxes) in the exceptionally profitable year $2005 .^{48}$ A loss of say 20 billion euros or more would dwarf these figures. It is emphasized that these figures are only used to put the size of the Dutch insurance market into perspective. In the U.S., where insurance capacity is much larger, private insurance against large-scale floods has already proved troublesome. It therefore seems highly unlikely that the Dutch insurance industry would be able to offer insurance against multibillion euro floods against a competitive rate. But even when a sizeable private insurance layer (e.g. a limit of 1 billion euro, comparable to the NHT) would be possible and attractively priced, one should consider the issue of moral hazard on part of the national government, that is, underinvestment in flood protection. To prevent underinvestment in flood protection, a sizeable private insurance layer would hardly seem attractive.

${ }^{43}$ Froot (2001); Jaffee and Russell (1997)

${ }^{44}$ Froot (2001); Froot and O'Connell (1999).

${ }^{45}$ For example, Doherty (2000); Jaffee and Russell (1997); Kielholz and Durrer (1997); Swiss Re (1998b). In 1992, the Chicago Board of Trade introduced catastrophe futures and options (D'Arcy and France (1992); Hoyt and Williams (1995)). The CBOT stopped trading cat-futures and cat-options in 1996 and 1999, respectively. Yet in 2007, the New York Mercantile Exchange (NYMEX) started trading catfutures and cat-options again. Because floods in the Netherlands are completely uncorrelated with a U.S. loss-index, the NYMEX cat-options and cat-futures are of no relevance to the insurance of flood risks in the Netherlands.

${ }^{46}$ Froot (2001).

${ }^{47}$ For example, Dutch Association of Insurers (2006, p. 17).

${ }^{48}$ Dutch Association of Insurers (2005). 
On the 29th of August 2005, Hurricane Katrina struck the U.S. Gulf Coast. The ensuing storm surge washed away numerous properties. The levee system protecting New Orleans proved no match for the surge and large parts of the low-lying city were flooded. The percentages of insured properties against floods ranged from 7.3 to 57.7 per cent. ${ }^{49}$ Under the NFIP, established in 1968, homeowners could have insured their properties at an actuarially fair premium. Owners of properties constructed prior to the establishment of flood insurance rate maps could even have obtained flood insurance at subsidized rates. ${ }^{50}$ Every rational risk adverse individual would have purchased such reasonably priced flood insurance. How then to explain the low levels of coverage in the Louisiana parishes affected by Katrina?

A possible explanation could be the expectation that relief would be offered by charities and governments in case of a major hurricane. Over the past century, the U.S. federal government has increasingly offered support to the victims of natural disasters. $^{51}$ This tendency might have bolstered expectations and created a severe moral hazard problem. According to the expected utility model, a non-zero probability of post-disaster assistance reduces the amount of coverage that a person wishes to purchase as well as the incentive to take cost-effective mitigation measures. ${ }^{52}$ The argument is undoubtedly valid within the realm of the expected utility model. But there seems to be no empirical evidence that supports the notion that disaster assistance affects people's decisions to purchase coverage for natural disasters. ${ }^{53}$

The main reason for property owners' lack of interest in purchasing insurance against natural disasters seems to concern people's perception of the probability of a catastrophe. ${ }^{54}$ Kunreuther suggests a sequential model of insurance purchase decisions in which people first "decide" whether a risk is something to worry about and then decide whether an insurance purchase would be an attractive coping strategy. This sequential model is consistent with the contingent weighting model proposed by Tversky et al. ${ }^{55}$ Individuals that are offered a complex choice will place weights on the dimensions of the problem at hand. These weights are contingent on the context of decision making. When people place zero weight on the probability of suffering a loss, they will not consider an insurance purchase worthwhile, even when insurance is available at a subsidized rate. The results are also consistent with experimental studies that showed that individuals are more likely to purchase insurance against highprobability, low-impact events than against low-probability, high-impact events. ${ }^{56}$ Based on these psychological studies and experiences with the U.S. NFIP, one could

\footnotetext{
${ }^{49}$ Kunreuther and Pauly (2006).

${ }^{50}$ Burby (2001).

${ }^{51}$ Moss (1999).

${ }^{52}$ For example, Priest (1996); Harrington (2000); Congressional Budget Office (2002).

${ }^{53}$ Kunreuther (1996).

${ }^{54}$ Kunreuther (1996); Kunreuther and Pauly (2006).

55 Tversky et al. (1998).

${ }^{56}$ Slovic et al. (1977).
} 
expect levels of coverage to be low when flood insurance in the Netherlands would be offered on a voluntary basis.

But why would low levels of coverage be problematic? One could advance two arguments. From a "paternalistic" perspective, one could argue that individuals are unlikely to act in a manner that would serve their interests best when offered the choice to purchase insurance. Although many would not consider the purchase of fairly priced insurance worthwhile, they probably should if there were no alternative means for loss compensation. The second argument concerns the costs of disaster assistance. Ad hoc responses by governments to disasters take place under tremendous time and political pressures and are therefore likely to be poorly targeted and inefficient. ${ }^{57}$

\section{A need for government involvement}

Given the supply- and demand-side restrictions discussed in the previous section, it seems that government involvement would be required along two fronts. First, the government would have to provide underwriting capacity to overcome the problems on the supply side. Second, the government would have to make insurance (semi-) compulsory to prevent adverse selection and problems related to a large percentage of the population ending up being uninsured. It might however be troublesome and costly to enforce a mandatory flood insurance scheme. Flood insurance could therefore also be statutorily included in fire insurance (as proposed in 1995 by the Dutch cabinet, and as is current practice in Belgium), hence the term "semicompulsory" (Table 1).

A deductible would be appropriate to prevent ex post moral hazard, that is, to provide homeowners an incentive to take preventive action when a flood warning is issued or when a flood occurs. Although a detailed discussion of the terms of contract is outside the scope of the present paper, different deductibles could be used for un-movables (properties) and contents. Deductibles for contents could perhaps be modeled after those in fire insurance. ${ }^{58}$ It should be noted that the government layer could itself also be layered. It could for instance involve a calamities fund, securitization, and debt issuance.

Although a strong financial commitment by the Dutch national government seems inevitable, government insurance/compensation programs are typically subject to strong criticisms. ${ }^{59}$ The critiques mainly concern the government's limited ability to pool risks and its poor track record in dealing with adverse selection and moral hazard. But these critiques do not seem to apply to the somewhat exceptional Dutch case.

First, let us consider the criticism related to cross-sectional diversification. While (re)insurance companies can pool earthquakes in Turkey, hurricanes in the U.S., and floods in the Netherlands, the Dutch government cannot. But this does not automatically mean that Dutch taxpayers would be confronted with a considerable

\footnotetext{
${ }^{57}$ For example, Kunreuther (1996); Kunreuther and Pauly (2006); Thieken et al. (2006).

58 See also Swiss Re (2005).

${ }^{59}$ For example, Priest (1996); Harrington (2000).
} 
The Geneva Papers on Risk and Insurance - Issues and Practice

262

Table 1 Government interventions to resolve the uninsurability of large-scale floods

\begin{tabular}{llll}
\hline Rationale & Intervention & Government role & Objective \\
\hline $\begin{array}{l}\text { Supply-side } \\
\text { restrictions }\end{array}$ & $\begin{array}{l}\text { Provide underwriting } \\
\text { capacity }\end{array}$ & $\begin{array}{l}\text { Financial } \\
\text { intermediary }\end{array}$ & $\begin{array}{l}\text { Raise capital at an attractive rate } \\
\text { by exploiting the government's } \\
\text { superior creditworthiness }\end{array}$ \\
$\begin{array}{l}\text { Demand-side } \\
\text { restrictions }\end{array}$ & $\begin{array}{l}\text { Enforce (semi-) } \\
\text { compulsory insurance }\end{array}$ & Regulator & $\begin{array}{l}\text { Prevent adverse selection and avoid } \\
\text { a large percentage of uninsured }\end{array}$ \\
\hline
\end{tabular}

risk premium. While the government's ability to diversify flood risks cross-sectionally is undoubtedly limited, the government has a superior ability to diversify large-scale risks inter-temporally: the "contract" between taxpayers and the Dutch government is a "long-term contract." And because its probability of default is negligible (the government has an AAA-rating), the government is theoretically able to borrow at the risk-free rate and "sell" coverage at a price that corresponds to expected loss. ${ }^{60}$

Second, consider the issues of adverse selection and moral hazard. When insurance is assumed to be compulsory, the issue of adverse selection becomes irrelevant. ${ }^{61}$ But what about moral hazard? A government compensation program that is funded through general taxation would probably involve some degree of crosssubsidization. But this would unlikely give rise to a severe moral hazard problem in the Netherlands. After all, because people's contributions to flood prevention are compulsory (taxation), moral hazard on part of individual citizens cannot give rise to excessive risks.

The issue that remains is not related to efficiency but to distributive justice. Why should someone that is not exposed to flood risks share in the financial burden? The majority of the Dutch population lives in flood-prone areas: over 60 per cent. Given this vast percentage, it seems unlikely that people would not declare solidarity with flood victims. If, however, one feels that these costs should be borne exclusively by those at risk, adding risk-based premiums to the taxes paid to water boards could be an option. That way, only those at risk would (implicitly) pay for flood "insurance."

\section{Involving the insurance industry}

\section{Two possible roles for the insurance industry}

A strong role for the national government does not imply that there could not or should not be a role for the private insurance industry. The private insurance industry could play two roles that could, but need not, be combined: (i) insurers could provide claims management services and (ii) insurers could provide underwriting capacity. Contracting insurers to provide claims management services could offer advantages when insurers would be better able than the government to do so. The insurance

\footnotetext{
${ }^{60}$ Cummins et al. (1999).

${ }^{61}$ See also Swiss Re (1998a, b).
} 
Table 2 A flood insurance program involving a private insurance layer

\begin{tabular}{ll}
\hline Layer & Description \\
\hline 1. Self-insurance & $\begin{array}{l}\text { Property-owners carry part of their losses themselves to prevent ex post moral } \\
\text { hazard: this deductible is to stimulate people to keep losses to a minimum when a } \\
\text { flood occurs or seems imminent. }\end{array}$ \\
$\begin{array}{l}\text { Insurance companies cover losses up to a predefined level of corporate or industry- } \\
\text { wide loss. }\end{array}$ \\
$\begin{array}{l}\text { The governate } \\
\text { The government } \\
\text { the second layer is exhausted. The national government's financing strategy could } \\
\text { also involve layers, such as cat bonds and/or a calamities fund, supplemented by debt } \\
\text { issuance. }\end{array}$
\end{tabular}

industry could also be involved as provider of a (relatively modest) insurance layer. Three layers could be discerned when insurers would provide underwriting capacity: self-insurance, private insurance, and government assistance (Table 2).

As discussed in the previous section, a private insurance layer would have to be relatively small (e.g. 1 billion euros) because of the limited capacity of the private insurance industry (or the costs of coverage for large, low-probability losses) and because of the risk of moral hazard on part of the national government (underinvestment in flood protection). Whether a private insurance layer would be beneficial depends ultimately on the costs of such a layer compared to the costs of a government layer. But apart from the costs of coverage, two other aspects deserve attention when a private insurance layer is contemplated.

First, one should have regard for credit risk. Contract performance is rarely tested in case of low probability events: the Netherlands have not witnessed any major flood since 1953. Oversight would be highly important to reduce the probability of default. If the government were to assist flood victims when an insurer were to default on its obligation to pay claims, losses would effectively be borne by taxpayers.

Second, with the government responsible for flood protection, one should consider the possibility that (re)insurers escape liability or successfully charge the government with negligence. It seems likely that insurers would be released from the obligation to pay off policyholders when the terms of contract would stipulate that all flood defenses should comply with statutory design standards. After all, only a relatively small portion of the primary flood defenses passed the most recent quinquennial review. ${ }^{62}$ Although this issue could probably be solved without considerable difficulty, one should also consider the following situation. The government might decide to deliberately flood a polder to reduce the flood probability of a highly valuable region. Although it would obviously be a controversial decision to flood a polder, it is not a purely hypothetical one. Deliberate inundation can reduce the probability of flood elsewhere but the other polder might still be flooded (or not). It seems unlikely that a legal dispute would not arise afterwards over the presumed need for deliberate inundation.

\footnotetext{
${ }^{62}$ Ministry of Transport, Public Works and Water Management (2006).
} 


\section{The role of the government vis-à-vis the insurance industry}

When the insurance industry provides underwriting capacity, one should also consider the role of the government vis- $\grave{a}$-vis the insurance industry. Does the government act as a "reinsurer" that sells coverage for large losses, or does it act as a "backstop" that simply absorbs losses once the private insurance layer is exhausted?

Under the arrangement proposed by Lewis and Murdock, ${ }^{63}$ the national government would act as a reinsurer and sell XOL-contracts to the insurance industry for a layer that is currently unavailable at "reasonable" prices in the marketplace. An XOL-contract is effectively a call-spread: a call-option held by insurers (the government takes a long position in the losses exceeding the retention) and a putoption held by the national government (the government takes a short position in the losses exceeding the retention plus limit). Payout on the XOL-contracts could follow a simple linear function of industry-wide losses. Although basis risk might seem unacceptable, insurers could enter into risk-sharing agreements ex ante, as discussed by Lewis and Murdock.

The proposal by Lewis and Murdock was tailored to the U.S. insurance market. Here, their proposal is stretched to fit the Dutch context, which undoubtedly does scant justice to the institutional differences between the U.S. and the Netherlands. Lewis and Murdock for instance posed that a risk loading would strictly not be needed because of the government's superior ability to time diversify, but that a risk-loading could stimulate the development of a private (re)insurance market for large-scale losses. ${ }^{64}$ The program, when successful, would cause its own demise. The underlying idea is that reinsurance for large-scale losses is currently unavailable (too costly) in the U.S. because the market is not yet developed. But without competitively priced reinsurance, the market will not develop in the first place. If this "chicken and egg" problem were the full story for the uninsurability of large-scale floods in the Netherlands, compulsory insurance would surely resolve the problem of "uninsurability." But because flood risk in the Netherlands is highly concentrated, this hardly seems credible.

It should be kept in mind that the costs of government "reinsurance" would have to be borne by all taxpayers. And similarly, the gains from government "reinsurance" sales would accrue to all taxpayers. Auctioning XOL-contracts would in effect be a roundabout way to tax those at risk. After all, the costs of the XOL-contracts will be passed on to policyholders. But given the costs of setting up and managing a government XOL-program, it seems less expensive to have the government simply raise funds through the tax mechanism.

This brings us to the second possible government role: that of a "backstop." The government could simply absorb all losses that exceed some predefined level. With a free upper layer (no premium charged by the government to insurers), insurance coverage would be offered at actuarially unsound levels. After all, without the upper layer being priced, premiums charged to policyholders would only be based on a minor part of total loss. But from an efficiency perspective, this would not necessarily be an

\footnotetext{
${ }^{63}$ Lewis and Murdock (1996, 1999).

${ }^{64}$ Cummins et al. (1999); Lewis and Murdock (1996, 1999).
} 
issue (equity apart). After all, the issue of moral hazard concerns moral hazard on part of the government rather than moral hazard on part of individuals. Crosssubsidization is therefore unlikely to negatively influence the level of flood risk in the Netherlands.

\section{Concluding remarks}

Floods related to the failure of the Dutch primary flood defenses are high-impact, lowprobability events for which insurance is currently unavailable in the insurance market. The current Calamities Compensation Act hardly seems an adequate solution because of its discretionary nature and cap of only 500 million euros. Because multibillion euro losses (floods on the scale of New Orleans) are not unthinkable, and because poorly planned and targeted disaster assistance is likely to be inefficient and delay reconstruction, devising an arrangement for the financing of large-scale floods in the Netherlands seems of considerable importance.

The scale of potential losses relative to the size of the Dutch insurance industry and the Dutch economy as a whole presents formidable challenges. This sets the Dutch case apart from, for example, the U.S. where natural disasters could more easily be absorbed by governments and the insurance industry. Securitization could perhaps be a useful means to tap into capital markets and spread these concentrated risks around the globe. Cat-bonds have been issued mainly by private sector entities. But in 2006, FONDEN, an institution created by the Mexican government, engaged in a $\$ 160$ million cat-bond transaction. ${ }^{65}$ These cat-bonds were issued to help finance the Mexican government's relief and reconstruction efforts if a major earthquake were to occur. Whether and how cat-bonds could be part of an insurance arrangement for large-scale floods in the Netherlands are issues that deserve further study.

Another important difference between the Netherlands and other countries concerns moral hazard. The type of moral hazard that has to be addressed concerns moral hazard on the part of the government rather than moral hazard on the part of individuals. The national government, provinces, and water boards look after primary flood defenses. Money spent by hundreds of thousands of citizens to reduce their individual exposures would be more cost-effectively spent on flood defenses that benefit them all. Individuals cannot avoid their responsibilities because their contribution to the maintenance and construction of flood defenses is compulsory (taxation). This unusual situation puts the conventional wisdom that a government insurance/compensation program would be inefficient on its head.

A strong financial commitment by the national government would be appropriate to exploit the government's superior ability to diversify flood risks inter-temporally, and to prevent moral hazard on part of the government, that is, underinvestment in flood prevention. The latter is not a purely hypothetical issue as shown by experiences in the U.K. The insurance industry could perhaps be involved to provide claims management services and/or (limited) underwriting capacity.

${ }^{65}$ MMC Securities (2006). 
While various strategic choices have been outlined, detailed answers have not been given. Many operational issues are yet to be explored, such as the terms of contract and the ways to administer a Dutch flood insurance program. Ultimately, much depends not only on cost and risk estimates, but also on political preferences.

\section{Acknowledgements}

This paper presents results of a research project that was carried out at the Decision Support and Risk Group of the London School of Economics. The project was financially supported by the Prince Bernhard Cultural Foundation.

\section{References}

Arrow, J.K. (1971) Essays in the Theory of Risk-Bearing, Amsterdam and London: North-Holland Publishing Company.

Burby, R.J. (2001) 'Flood insurance and floodplain management: The US experience', Environmental Hazards 3: 111-122.

Congressional Budget Office (2002) Federal Reinsurance for Disasters, The Congress of the United States.

Cummins, J.D., Lewis, C.M. and Phillips, R.D. (1999) 'Pricing excess-of-loss reinsurance contracts against catastrophic loss', in K.A. Froot (ed) The Financing of Catastrophe Risk, Chicago and London: The University of Chicago Press.

D’Arcy, S.P. and France, G.F. (1992) 'Catastrophe futures: A better hedge for insurers', The Journal of Risk and Insurance 59: 575-601.

De Vries, F.J. (1998) 'Vergoeding van Rampschade', Nederlands Juristenblad 20: 1908-1915.

Disasters and Calamities Compensation Committee (2004) (in Dutch: Commissie Tegemoetkoming bij Rampen en Calamiteiten) Tactful Solidarity (in Dutch: 'Solidariteit met beleid'), The Hague.

Doherty, N.A. (2000) 'Innovation in corporate risk management: The case of catastrophic risk', in G. Dionne (ed) Handbook of Insurance, New York: Kluwer Academic Publishers.

Doherty, N.A. and Smith Jr., C.W. (1993) 'Corporate insurance strategy: The case of British Petroleum', Journal of Applied Corporate Finance 6: 4-15.

Dutch Association of Insurers (2005) Financieel Jaarverslag Verzekeringsbranche 2005, The Hague: Centrum voor Verzekeringsstatistiek.

Dutch Association of Insurers (2006) Kernpunten 2005-2006, The Hague.

Faure, M.G. (2006) 'Financial compensation for victims of catastrophes: A law and economics perspective', Law \& Policy 29: 339-367.

Faure, M.G. and Hartlief, T. (eds) (2006) Financial Compensation for Victims of Catastrophes: A Comparative Legal Approach, Vienna: Springer.

Flood Defence Act (1995) Law of 21 December 1995, Containing General Rules to Ensure Protection by Flood Defences Against Floods Caused by Outside Waters, and Regulation of Some Related Affairs (in Dutch: Wet van 21 december 1995, houdende algemene regels ter verzekering van de beveiliging van de waterkeringen tegen overstromingen door het buitenwater en regeling van enkele daarmee verband houdende aangelegenheden), The Hague.

Froot, K.A. (2001) 'The market for catastrophic risk: A clinical examination', Journal of Financial Economics 60: 529-571.

Froot, K.A. and O'Connell, P.G.J. (1999) 'The pricing of U.S. catastrophe reinsurance', in K.A. Froot (ed) The Financing of Catastrophe Risk, Chicago and London: The University of Chicago Press.

Guy Carpenter (2006) The World Catastrophe Reinsurance Market; Steep Peaks Overshadow Plateaus, London: Guy Carpenter.

Harrington, S.E. (2000) 'Rethinking Disaster Policy; Breaking the cycle of 'free' disaster assistance, subsidized insurance, and risky behavior', Regulation 23: 40-46.

Hartlief, T. (2006) 'De maatschappelijk verantwoord handelende verzekeraar en problemen van verzekerbaarheid', Economenblad, 18-21. 
Hoyt, R.E. and Williams, R.D. (1995) 'The effectiveness of catastrophe futures as a hedging mechanism for insurers; an empirical and regulatory analysis', Journal of Insurance Regulation 14: 27-64.

Huber, M. (2004a) 'Insurability and regulatory reform: Is the English flood insurance regime able to adapt to climate change?', The Geneva Papers on Risk and Insurance - Issues and Practice 29: 169-182.

Huber, M. (2004b) Reforming the UK Flood Insurance Regime, The Breakdown of a Gentlemen's Agreement, London: London School of Economics.

Huisman, P. (2004) Water in the Netherlands: Managing Checks and Balances, Utrecht: Netherlands Hydrological Society.

Jaffee, D.M. and Russell, T. (1997) 'Catastrophe insurance, capital markets and uninsurable risks', The Journal of Risk and Insurance 64: 205-230.

Kielholz, W. and Durrer, A. (1997) 'Insurance derivatives and securitization new hedging perspectives for the US Cat Insurance Market', The Geneva Papers on Risk and Insurance - Issues and Practice 22: 3-16.

Kok, M. (2005) Flood insurance in the Netherlands: Feasible and desirable? (in Dutch: 'Een waterverzekering in Nederland: mogelijk en wenselijk?'), HKV Lijn in water.

Kok, M., Vrijling, J.K., Van Gelder, P.H.A.J.M. and Vogelsang, M.P. (2002) 'Risk of flooding and insurance in The Netherlands', in B.S. Wu (ed) Flood Defence, New York: Science Press Ltd.

Kunreuther, H. (1996) 'Mitigating disaster losses through insurance', Journal of Risk and Uncertainty 12: 171-187.

Kunreuther, H. and Pauly, M. (2006) 'Rules rather than discretion: Lessons from Hurricane Katrina', Journal of Risk and Uncertainty 33: 101-116.

Lewis, C.M. and Murdock, K.C. (1996) 'The role of government contracts in discretionary reinsurance markets for natural disasters', The Journal of Risk and Insurance 63: 567-597.

Lewis, C.M. and Murdock, K.C. (1999) 'Alternative means of redistributing catastrophic risk in a national risk-management system', in K.A. Froot (ed) The Financing of Catastrophe Risk, Chicago and London: The University of Chicago Press.

Ministry of Transport, Public Works and Water Management (2005) Floris-Study: Full Report, The Hague.

Ministry of Transport, Public Works and Water Management (2006) Primaire waterkeringen getoetst; Landelijke Rapportage Toetsing, The Hague.

MMC Securities (2006) The Catastrophe Bond Market at Year-End 2006; Ripples into Waves, Raleigh, North Carolina: Guy Carpenter.

Moss, D.A. (1999) 'Courting disaster? The transformation of federal disaster policy since 1803', in K.A. Froot (ed) The Financing of Catastrophe Risk, Chicago and London: The University of Chicago Press.

Priest, G.L. (1996) 'The government, the market, and the problem of catastrophe loss', Journal of Risk and Uncertainty 12: 219-237.

Raad van State (1996) Aanspraak op vergoeding zoetwateroverstromings- en aardbevingsschade, The Hague.

Rees, R. (1985a) 'The theory of principal and agent: Part 1', Bulletin of Economic Research 37: 3-26.

Rees, R. (1985b) 'The theory of principal and agent: Part 2', Bulletin of Economic Research 37: 75-95.

RIVM-MNP (2004) Risico's in bedijkte termen, een evaluatie van het beleid inzake de veiligheid tegen overstromen, The Hague: RIVM-MNP

Slovic, P., Fischhoff, B., Lichteinstein, S., Corrigan, B. and Combs, B. (1977) 'Preferences for insuring against probable small losses: Insurance implications', Journal of Risk and Insurance 44: 237-257.

Swiss Re (1998a) Floods - an insurable risk? A market survey, Zurich: Swiss Reinsurance Company.

Swiss Re (1998b) Floods - An Insurable Risk?, Zurich: Swiss Reinsurance Company.

Swiss Re (2004) 'Annual Review: Natural catastrophes 2004', in Topics Geo, Zurich: Swiss Reinsurance Company.

Swiss Re (2005) 'Innovating to insure the uninsurable', Sigma 4: 19-32.

Thieken, A.H., Petrow, T., Kreibich, H. and Merz, B. (2006) 'Insurability and mitigation of flood losses in private households in Germany', Risk Analysis 26: 383-395.

Tversky, A., Slovic, P. and Sattah, S. (1988) 'Contingent weighting in judgment and choice', Psychological Review 95: 371-384.

Van Dantzig, D. (1956) 'Economic decision problems for flood prevention', Econometrica 24: $276-287$.

Vari, A., Linnerooth-Bayer, J. and Ferenz, Z. (2003) 'Stakeholder views on flood risk management in Hungary's upper Tisza Basin', Risk Analysis 23: 585-600.

Water Advisory Council (2006) Recommendations of the Water Advisory Board Concerning the Insurance of Flooding (in Dutch: 'Aanbevelingen van de Adviescommissie Water inzake verzekeren en wateroverlast'), The Hague. 


\section{About the authors}

Ruben Jongejan is a $\mathrm{PhD}$ student at the section of Hydraulic Engineering at Delft University of Technology, the Netherlands. He holds a master's degree in Civil Engineering from Delft University, and a master's degree in Political Science from Leiden University (both cum laude). His main research interests are risk regulation and reliability engineering, with a particular focus on industrial and flood risks. Besides his studies at Delft University, he serves on two committees of the Netherlands Hazardous Substances Council, and works as a consultant in the field of risk management and reliability engineering.

Pauline Barrieu is a Reader in the Statistics department at the London School of Economics. She has two PhDs, both with highest honours: in Applied Mathematics from Paris VI and in Finance from the HEC Graduate Business School (France). For the latter she was awarded the Prix Actuariat 2003 for the best Actuarial PhD in Europe. In June 2006, one of her research papers "Inf-convolution of risk measures and optimal risk transfer" written with Nicole El Karoui, received the award for the best research paper in quantitative finance by the Europlace Institute of Finance. Her research interests are mainly on the study of problems at the interface between finance and insurance, in particular the design of illiquid products and the securitization of non-financial risks. She also works on quantitative methods for risk measurement and robust decision taking, with applications in finance and environmental economics. 